\title{
Brain-Derived Neurotrophic Factor (BDNF) protein levels in anxiety disorders: systematic review and meta-regression analysis
}

\author{
Sharain Suliman ${ }^{1 *}$, Sian M. J. Hemmings ${ }^{2}$ and Soraya Seedat ${ }^{3}$ \\ ${ }^{1}$ MRC Anxiety Disorders Unit, Department of Psychiatry, Faculty of Medicine and Health Sciences, University of Stellenbosch, Cape Town, South Africa \\ 2 Division of Molecular Biology and Human Genetics \& Department of Psychiatry, Faculty of Medicine and Health Sciences, University of Stellenbosch, Cape Town, \\ South Africa \\ ${ }^{3}$ Department of Psychiatry, Faculty of Medicine and Health Sciences, University of Stellenbosch, Cape Town, South Africa
}

\section{Edited by:}

Sidney A. Simon, Duke University, USA

Reviewed by:

Albino J. Oliveira-Maia,

Champalimaud Foundation, Portugal

Anne E. West, Duke University

Medical Center, USA

*Correspondence:

Sharain Suliman, MRC Anxiety

Disorders Unit, Department of

Psychiatry, University of

Stellenbosch, PO Box 19063

Tygerberg, 7505 Cape Town,

South Africa

e-mail:sharain@sun.ac.za
Background: Brain-Derived Neurotrophic Factor (BDNF) is a neurotrophin that is involved in the synaptic plasticity and survival of neurons. BDNF is believed to be involved in the pathogenesis of several neuropsychiatric disorders. As findings of BDNF levels in anxiety disorders have been inconsistent, we undertook to conduct a systematic review and metaanalysis of studies that assessed BDNF protein levels in these disorders.

Methods: We conducted the review using electronic databases and searched reference lists of relevant articles for any further studies. Studies that measured BDNF protein levels in any anxiety disorder and compared these to a control group were included. Effect sizes of the differences in BDNF levels between anxiety disorder and control groups were calculated.

Results: Eight studies with a total of 1179 participants were included. Initial findings suggested that BDNF levels were lower in individuals with any anxiety disorder compared to those without [Standard Mean Difference $(S M D)=-0.94(-1.75,-0.12), p \leq 0.05$ ] This was, however, dependent on source of BDNF protein [plasma: SMD $=-1.31(-1.69$, $-0.92), p \leq 0.01$; serum: $\operatorname{SMD}=-1.06(-2.27,0.16), p \geq 0.01]$ and type of anxiety disorder [PTSD: SMD $=-0.05(-1.66,1.75), p \geq 0.01 ; \mathrm{OCD}: \mathrm{SMD}=-2.33(-4.21$, $-0.45), p \leq 0.01]$.

Conclusion: Although BDNF levels appear to be reduced in individuals with an anxiety disorder, this is not consistent across the various anxiety disorders and may largely be explained by the significantly lowered BDNF levels found in OCD. Results further appear to be mediated by differences in sampling methods. Findings are, however, limited by the lack of research in this area, and given the potential for BDNF as a biomarker of anxiety disorders, it would be useful to clarify the relationship further.

Keywords: anxiety, BDNF, protein, meta-regression, systematic review

\section{BACKGROUND}

Brain-Derived Neurotrophic Factor (BDNF) is a neurotrophin (NT) which promotes the proliferation, survival and differentiation of neurons in the peripheral and central nervous systems (Lindsay et al., 1994; Aydemir et al., 2006). Although $\mathrm{BDNF}$ is more concentrated in brain tissue, it is present in the bloodstream and derives from different sources, including platelets and brain (Yamamoto and Gurney, 1990; Radka et al., 1996; Lommatzsch et al., 2005). There have been reports that BDNF can cross the blood-brain barrier (Pan et al., 1998) and positive correlations between peripheral BDNF protein levels and brain levels have been reported in rodents (Karege et al., 2002a,b), suggesting that peripheral BDNF levels may reflect BDNF levels in the brain. BDNF blood levels have also been shown to correlate with cortical integrity (Lang et al., 2007). In clinical settings, peripheral blood levels (i.e., serum or plasma) are thus widely used as a proxy for central levels.

Although our understanding of BDNF expression remains incomplete, hormones such as estradiol and testosterone, as well as glucocorticoids (GCs), have emerged as important mediators of BDNF expression and function, and there have been suggestions of functional interaction between BDNF and GCs, such as in the regulation of corticotrophin-releasing hormone and other important neuropeptides (Carbone and Handa, 2013). BDNF may thus possibly regulate the response to stress through transmitter systems that regulate the hypothalamus-pituitaryadrenal (HPA) axis (Smith et al., 1995; Champagne and Meaney, 2001; Duval et al., 2004). Early life stress may continue to exert effects into adulthood by repeated activation of stress-responsive biological mediators such as GC and catecholamines (McEwen and Stellar, 1993; McEwen, 1998). Notably, BDNF and other 
neurotrophic factors are believed to counteract the negative impact of stress hormones on hippocampal volume (Duman, 2002; Manji et al., 2003). BDNF has been shown to be involved in anxiety-like behaviors in animal models, and numerous types of stressors have been found to cause reduced expression of BDNF (Hartmann et al., 2001; Duman, 2002; Rasmusson et al., 2002).

BDNF is also thought to be involved in the pathogenesis of several neuropsychiatric disorders, and numerous studies have examined BDNF protein levels in humans, mostly in relation to depression (Karege et al., 2005; Molendijk et al., 2011a). Although BDNF lacks diagnostic specificity, findings of BDNF alterations across a number of psychiatric disorders, underscores the shared common pathophysiological mechanisms and high rates of comorbidity (Sen et al., 2008). Serum BDNF levels have been shown to correlate with antidepressant efficacy and to predict an individual's response to antidepressant treatment at an early time point following treatment initiation. For example, recent meta-analyses have confirmed significantly lower BDNF protein levels for depressed patients relative to concentrations found in healthy controls (Bocchio-Chiavetto et al., 2010), with levels normalizing after treatment with antidepressants (Brunoni et al., 2008; Sen et al., 2008). Work has also shown that the combination of early serum BDNF non-increase plus early nonimprovement on the Hamilton Depression Rating Scale predicted final treatment failure with $100 \%$ specificity (Tadić et al., 2011). These findings are mirrored by recent preliminary evidence of epigenetic (methylation) changes in the BDNF gene and inadequate antidepressant response in major depression (Tadić et al., 2013). These findings suggest that BDNF levels are likely to be a biomarker for depression and associated disorders, and support the notion that improvement of symptoms might be associated with the neuroplastic changes achieved by antidepressant treatment (Hashimoto, 2010). Furthermore, BDNF levels may help the clinician to predict clinical outcome. For example, findings by Kurita et al. (2012) indicate that if plasma BDNF levels decrease or are unchanged in an individual with regularly measured plasma BDNF, the clinician may need to re-evaluate treatment strategy.

Additionally, studies in human post-mortem brains have shown an involvement of BDNF in the pathophysiology of stressrelated psychopathologies, such as mood and anxiety disorders (Duman and Monteggia, 2006; Carola et al., 2008; Dunham et al., 2009) and a review by Molendijk et al. (2012) suggests that BDNF expression contributes to psychopathological characteristics. Given the high level of comorbidity between depressive and anxiety disorders, and the similarities in their pathophysiology (Kendler et al., 1992, 1995; Klaassen et al., 1998; Maron et al., 2004; David et al., 2009), it is plausible that BDNF levels in anxiety disorders may mirror the changes found in depression and potentially serve as a peripheral biomarker. Findings of BDNF protein levels in anxiety disorders, in animal models (Chen et al., 2006; Govindarajan et al., 2006; Monteggia et al., 2007) and in humans (Maina et al., 2010; Molendijk et al., 2011b; Wang et al., 2011) have, however, been inconsistent. To date, there has been no published meta-analysis of BDNF protein levels in anxiety. Clarifying these findings is important in elucidating the relevance and clinical application of BDNF measures in the diagnosis and treatment of anxiety disorders. Further investigation of the predictive clinical utility in guiding antidepressant treatment in randomized controlled trials is warranted as it may have implications for the treatment of anxiety disorders and guide more rationale prescribing.

We thus undertook to systematically review all studies, in particular controlled studies, of BDNF protein levels [in serum, plasma, or cerebrospinal fluid (CSF)] in anxiety disorders [acute stress disorder (ASD), agoraphobia (AGP), generalized anxiety disorder (GAD), obsessive-compulsive disorder (OCD), phobia, panic disorder (PD), posttraumatic stress disorder (PTSD), social phobia/ social anxiety disorder (SAD)]. We sought, firstly, to assess whether BDNF protein levels were lower in individuals with anxiety disorders than in those without, and secondly whether there was any specificity of effect with regards to the different anxiety disorders (ASD, AGP, GAD, OCD, phobia, PD, PTSD, SAD).

\section{METHODS CRITERIA FOR CONSIDERING STUDIES FOR THIS REVIEW}

We included any study that assessed for BDNF protein levels in adults or children with an anxiety disorder compared to a control group, regardless of sample size or ethnic background. Diagnoses were determined by psychiatric interviews, based on DSM-IV or ICD-10 criteria, in all studies. The outcome of interest was plasma, serum or CSF BDNF expressed as picograms (pg) or nanograms (ng).

\section{SEARCH STRATEGY FOR IDENTIFICATION OF STUDIES}

Studies were identified through the following databases: Academic Search Premier, Africa Wide Information, CAB Abstracts, CINAHL, E-Journals, Eric, Healthsource: Nursing/ Academic Edition, Pubmed and PsycArticles, between 18 June and 27 September 2012. Reference lists of pertinent articles were searched to identify any further relevant studies.

Search terms included a combination of "BDNF" or "brainderived neurotrophic factor" with each of the following: "acute stress disorder," "agoraphobia," "anxiety," "generalized anxiety disorder," "obsessive-compulsive disorder," "phobia," "panic," "posttraumatic stress disorder," "social anxiety disorder," "social phobia," "stress." No limit on the time period was applied to the search in order to avoid omission of relevant studies but the searches were restricted to the English language and humans. We excluded systematic and non-systematic review articles and studies of no direct relevance to the review.

Titles and abstracts of all original research articles identified were screened for eligibility and any abstract deemed potentially relevant was then reviewed in full text. The search and dataextraction were conducted separately by the first 2 authors and any uncertainty was discussed amongst the authors.

\section{DATA EXTRACTION AND ANALYSES}

Information extracted included study and population characteristics, sample size, study design, and outcomes relevant to this review. Means and standard deviations of BDNF levels were extracted and used to calculated the standard mean difference (SMD) and 95\% confidence interval (CI) for individual studies 
and where appropriate to conduct meta-analyses. Information not available in a research article was obtained through the authors of that publication, where possible. We used the inversevariance statistical method and, as we expected significant heterogeneity, a random-effects analyses model. Subgroup analyses were performed for the different anxiety disorders, if there was more than one study in the group. Sensitivity analyses were also performed to determine if results differed depending on whether (1) only studies assessing serum levels and (2) only studies assessing plasma levels were included.

\section{RESULTS}

The database searches yielded a total of 4493 results. Fifty abstracts were identified as potentially relevant and full manuscripts were obtained. Of these, 37 were excluded as they were not of relevance to the present review. Full texts of the 13 studies that appeared relevant were then reviewed in greater detail, and eight studies, with a total of 1179 participants, were found to meet inclusion criteria (see Figure 1). The following information was uniformly extracted from each study: first author's name, year of publication, source of publication, study characteristics (where study took place, study type), participant characteristics (age, gender, type of anxiety disorder, number of cases, and controls), measures of anxiety and BDNF. The reviewed studies are summarized in Tables $\mathbf{1}$ (table of included studies) and 2 (table of excluded studies). There was heterogeneity in sample characteristics, study methodology and measures of outcome i.e., BDNF protein levels were measured as serum, plasma and CSF and different units of measurement were used across studies (ng

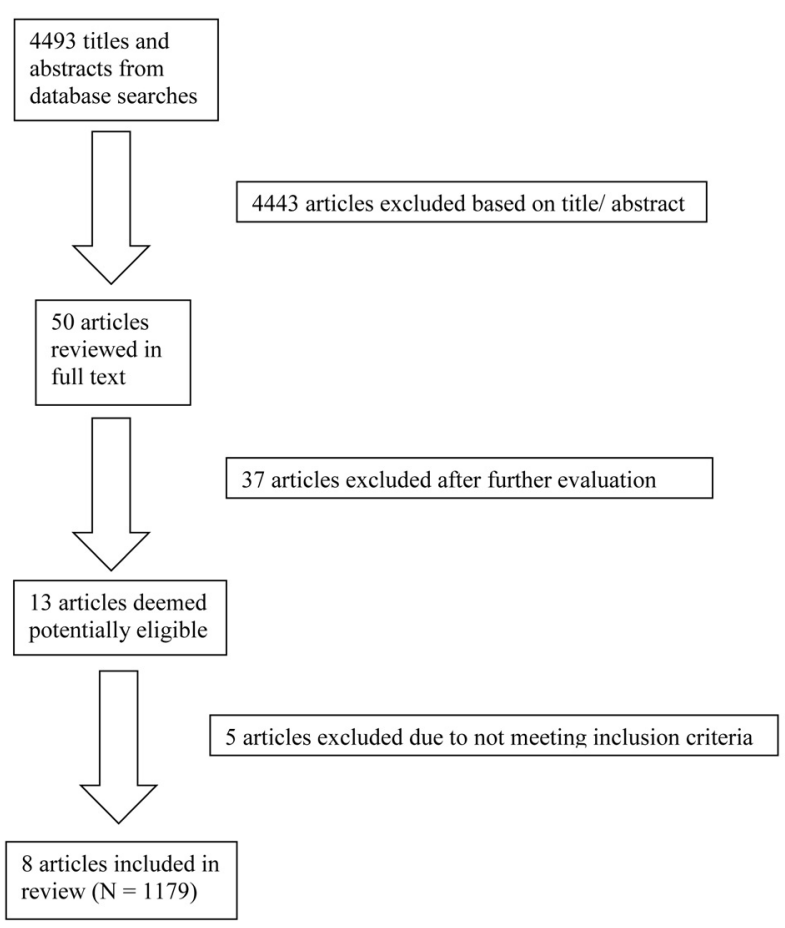

FIGURE 1 | Flow diagram of review process. or $\mathrm{pg} / \mathrm{ml}$ and $\mathrm{pg} / \mu \mathrm{g})$, limiting comparability. We report all BDNF levels in $\mathrm{pg} / \mathrm{ml}(1 \mathrm{ng} / \mathrm{ml}=1000 \mathrm{pg} / \mathrm{ml}$ or $\mathrm{pg} / \mu \mathrm{g})$.

\section{DESCRIPTION OF STUDIES Included studies}

Three studies assessed BDNF protein levels in patients with PTSD or ASD and compared them to non-traumatized, healthy controls. The Bonne study (Bonne et al., 2011) was conducted in the USA. It was an interventional study that assessed CSF BDNF levels in a cohort of 16 medication-free, non-combat related PTSD patients and 11 control participants. Participants with alcohol or substance abuse or dependence in the last six months were excluded; however, participants with current or past depression and other anxiety disorders were not excluded. In patients with PTSD, BDNF levels were assessed prior to and post 12 weeks of treatment with paroxetine. The PTSD group was older (mean age $36 \pm 11.4$ years) and comprised a greater proportion of females $(75 \%)$ than the control group (mean age $35.3 \pm 13.1$ years, $64 \%$ female). Patients with PTSD were more likely than controls to have more anxiety and depressive symptoms and to meet criteria for past MDD. For the purpose of this review we only considered pre-treatment data. Patients with PTSD were found to have similar concentrations of BDNF when compared to healthy controls $(1 \pm 0.52 \mathrm{pg} / \mathrm{ml}$ vs. $0.83 \pm 0.44 \mathrm{pg} / \mathrm{ml}, p>0.05)$.

Dell'Osso et al. (2009) conducted a cross-sectional, casecontrolled study in Italian participants. Plasma BDNF levels were assessed in 18 medication free outpatients with PTSD $(67 \%$ female) and 18 healthy controls (61\% female). Exclusion criteria included: current or lifetime diagnosis of organic mental disorder, schizophrenia, schizophreniform or other psychotic disorders, bipolar disorders, substance-related disorders, a current diagnosis of depressive disorder, uncontrolled or severe medical conditions, and any current or past psychopharmacological treatment. Patients had a mean age of $42.1 \pm 12.5$ years and controls of $38.8 \pm 12.1$ years. BDNF levels were significantly lower in patients than controls $(5300 \pm 1100 \mathrm{pg} / \mathrm{ml}$ vs. $7400 \pm 1500 \mathrm{pg} / \mathrm{ml}, p<$ $0.001)$. BDNF levels did not correlate with any other demographic or clinical characteristic assessed.

The Hauck et al. (2010) study was also a cross-sectional, casecontrolled study, conducted in Brazilian participants. Thirty-four outpatients with ASD or PTSD (21 who had experienced a traumatic event in the previous year, 13 who had experienced it more than 4 years before assessment) were compared with 34 ageand gender- matched healthy controls. Exclusion criteria comprised neurodegenerative disorders, psychotic symptoms, mental retardation, cancer and/or chronic/acute infection. Females comprised $79 \%$ of each group. More than a third (41\%) of patients were using psychotropic medications at the time of assessment. Patients were younger (mean age $35.2 \pm 13$ years) than controls (mean age $36.2 \pm 9.2$ years) and had significantly higher serum BDNF levels than controls $(0.49 \pm 0.21 \mathrm{pg} / \mu \mathrm{g}$ vs. $0.25 \pm 0.14$ $\mathrm{pg} / \mu \mathrm{g}, p<0.001)$. However, when the patient group was stratified by recent and remote trauma, and compared with controls, only those who had experienced recent trauma had significantly higher BDNF levels $(p<0.001)$. The authors noted that the two patient groups did differ in terms of PTSD symptoms. However, there were no correlations between BDNF levels and any of the 
Table 1 | Included studies.

\begin{tabular}{|c|c|c|c|c|c|}
\hline Author & $N($ Anxiety \pm$)$ & Setting and participants & $\begin{array}{l}\text { Study type and } \\
\text { design }\end{array}$ & $\begin{array}{l}\text { Outcomes of interest and } \\
\text { assessment measures }\end{array}$ & $\begin{array}{l}\text { BDNF levels in patients } \\
\text { vs. controls (mean, } S D \text {, } \\
p \text {-value) }\end{array}$ \\
\hline $\begin{array}{l}\text { Bonne et al., } \\
2011\end{array}$ & $25(16 / 11)$ & $\begin{array}{l}\text { USA; } 16 \text { medication-free outpatients } \\
\text { with chronic PTSD, } 12 \text { female; } 11 \\
\text { non-traumatized healthy controls, } 7 \\
\text { female; ages 18-65 }\end{array}$ & $\begin{array}{l}\text { Interventional study; } \\
\text { cohort assessed pre- } \\
\text { and post- treatment } \\
\text { with paroxetine }\end{array}$ & $\begin{array}{l}\text { PTSD; Diagnosis: SCID-CV } \\
\text { (First et al., 1996) Severity: } \\
\text { CAPS Blake et al., } 1995 \\
\text { BDNF: CSF }\end{array}$ & $\begin{array}{l}1.00 \pm 0.52 \text { vs. } 0.83 \pm \\
0.44 ; p>0.05(\mathrm{pg} / \mathrm{ml})\end{array}$ \\
\hline $\begin{array}{l}\text { Dell'Osso } \\
\text { et al., } 2009\end{array}$ & $36(18 / 18)$ & $\begin{array}{l}\text { Italy; } 18 \text { medication-free outpatients } \\
\text { with PTSD, } 12 \text { female; } 18 \\
\text { non-traumatized healthy controls, } 11 \\
\text { female); ages 18-65 }\end{array}$ & $\begin{array}{l}\text { Cross-sectional, case } \\
\text { controlled study }\end{array}$ & $\begin{array}{l}\text { PTSD; Diagnosis: SCID-I/P } \\
\text { (First et al., 1995) Severity: } \\
\text { IES (Horowitz et al., 1979) } \\
\text { BDNF: plasma }\end{array}$ & $\begin{array}{l}5300 \pm 1100 \text { vs. } 7400 \pm \\
1500 ; p<0.001(\mathrm{pg} / \mathrm{ml})\end{array}$ \\
\hline $\begin{array}{l}\text { dos Santos } \\
\text { et al., } 2011\end{array}$ & $50(25 / 25)$ & $\begin{array}{l}\text { Brazil; } 25 \text { medication-free outpatients } \\
\text { with OCD, } 21 \text { female; } 25 \text { healthy } \\
\text { controls, } 20 \text { female; ages } 18-60\end{array}$ & $\begin{array}{l}\text { Cross-sectional, case } \\
\text { controlled study }\end{array}$ & $\begin{array}{l}\text { OCD; Diagnosis: SCID-I/P } \\
\text { (First et al., 1995) Severity: } \\
\text { Y-BOCS (Goodman et al., } \\
\text { 1989) BDNF: serum }\end{array}$ & $\begin{array}{l}0.470 \pm 0.038 \text { vs. } 0.747 \text { vs } \\
0.060 ; p<0.001(\mathrm{pg} / \mu \mathrm{g})\end{array}$ \\
\hline $\begin{array}{l}\text { Hauck et al., } \\
2010\end{array}$ & $68(34 / 34)$ & $\begin{array}{l}\text { Brazil; } 34 \text { outpatients with ASD or } \\
\text { PTSD ( } 21 \text { recent trauma, } 13 \text { remote } \\
\text { trauma), } 27 \text { female; } 41 \% \text { of patients } \\
\text { using psychotropic medication; } 34 \text { age- } \\
\text { and gender-matched healthy controls), } \\
27 \text { female; ages 14-65 }\end{array}$ & $\begin{array}{l}\text { Cross-sectional, case } \\
\text { controlled study }\end{array}$ & $\begin{array}{l}\text { PTSD; Diagnosis: MINI } \\
\text {-Portuguese version (Sheehan } \\
\text { et al., 1998; Amorin, 2000) } \\
\text { Severity: DTS (Davidson } \\
\text { et al., 1997) BDNF: serum }\end{array}$ & $\begin{array}{l}0.49 \pm 0.21 \text { vs. } 0.25 \pm \\
0.14, p<0.01(\mathrm{pg} / \mu \mathrm{g})\end{array}$ \\
\hline $\begin{array}{l}\text { Maina et al., } \\
2010\end{array}$ & $48(24 / 24)$ & $\begin{array}{l}\text { Italy; } 24 \text { medication-free outpatients } \\
\text { with OCD and no recent psychological } \\
\text { stressors, } 9 \text { female; } 24 \text { healthy age- } \\
\text { and gender-matched controls, } 9 \\
\text { female; ages 18-65 }\end{array}$ & $\begin{array}{l}\text { Cross-sectional, case } \\
\text { controlled study }\end{array}$ & $\begin{array}{l}\text { OCD; Diagnosis: SCID (First } \\
\text { et al., 1996, 1997) Severity: } \\
\text { Y-BOCS (Goodman et al., } \\
\text { 1989) BDNF: serum }\end{array}$ & $\begin{array}{l}36,900 \pm 6420 \text { vs. } 41,590 \\
\pm 7820 ; p<0.05(\mathrm{pg} / \mathrm{ml})\end{array}$ \\
\hline $\begin{array}{l}\text { Molendijk } \\
\text { et al., 2011a }\end{array}$ & $775(393 / 382)$ & $\begin{array}{l}\text { Netherlands; } 393 \text { medication-free } \\
\text { outpatients with any anxiety disorder } \\
\text { except OCD, } 262 \text { female; } 382 \text { healthy } \\
\text { controls, } 237 \text { female; ages 18-65 }\end{array}$ & $\begin{array}{l}\text { Cross-sectional, } \\
\text { cohort study }\end{array}$ & $\begin{array}{l}\text { Anxiety Disorders: Diagnosis: } \\
\text { CIDI (Wittchen et al., 1991) } \\
\text { Severity: not assessed; } \\
\text { BDNF: serum }\end{array}$ & $\begin{array}{l}9310 \pm 3380 \text { vs. } 9490 \pm \\
3180 ; p>0.05(\mathrm{pg} / \mathrm{ml})\end{array}$ \\
\hline $\begin{array}{l}\text { Strohle et al., } \\
2010\end{array}$ & $24(12 / 12)$ & $\begin{array}{l}\text { Germany; } 12 \text { medication-free } \\
\text { outpatients with PD (10 with Agora), } 9 \\
\text { female; } 12 \text { age- and gender-matched } \\
\text { controls, } 9 \text { female; ages 18-65 }\end{array}$ & $\begin{array}{l}\text { Interventional, } \\
\text { case-controlled study; } \\
\text { participants assessed } \\
\text { pre- and } \\
\text { post-excercise }\end{array}$ & $\begin{array}{l}\text { PD; Diagnosis: MINI } \\
\text { (Sheehan et al., 1998) } \\
\text { Severity: the panic and } \\
\text { agoraphobia scale (Bandelow, } \\
\text { 1997) BDNF: serum }\end{array}$ & $\begin{array}{l}2700.2 \pm 4184.9 \text { vs } \\
9700.45 \pm 7291.15 \\
p<0.01(\mathrm{pg} / \mathrm{ml})\end{array}$ \\
\hline $\begin{array}{l}\text { Wang et al., } \\
2011\end{array}$ & $137(74 / 63)$ & $\begin{array}{l}\text { China; } 22 \text { medication-free and } 52 \\
\text { medication-treated outpatients with } \\
\text { OCD, } 26 \text { female; } 63 \text { age and gender } \\
\text { matched controls, } 30 \text { female; ages } \\
\text { 18-64 }\end{array}$ & $\begin{array}{l}\text { Cross-sectional, case } \\
\text { controlled study }\end{array}$ & $\begin{array}{l}\text { OCD; Diagnosis: MINI } \\
\text { (Sheehan et al., 1998) } \\
\text { Severity: Y-BOCS (Kim et al., } \\
\text { 1990) BDNF: plasma }\end{array}$ & $\begin{array}{l}1980 \pm 1590 \text { vs. } 4090 \pm \\
2000 ; p<0.01(\mathrm{pg} / \mathrm{ml})\end{array}$ \\
\hline
\end{tabular}

clinical rating scales used. A limitation of this study is that not all patients were drug-free, although this was not found to interfere with BDNF levels in the sample.

Three studies assessed BDNF protein levels in OCD patients and compared them to healthy controls. dos Santos and colleagues (2011) conducted a cross-sectional, case-controlled study comparing 25 un-medicated (medication free for $>60$ days) OCD outpatients with 25 healthy controls. Exclusion criteria considered were: current history of alcohol or any other substance use or abuse, history of encephalic/brain trauma followed by posttraumatic amnesia, current history of any other neurological or systemic disorders (i.e., epilepsy, Parkinson's disease, or systemic lupus), current use of medication that could lead to any psychopathological manifestations, current suicide risk, pregnant or breast-feeding women, $<18$ and $>60$ years of age, and a cognitive deficit that could result in an inability to understand the instruments and questionnaires. Mean age of patients was $44.1 \pm 2.82$ years and of controls was $37.44 \pm 3.09$ years. Eighty four percent of the OCD group was female compared to $80 \%$ in the control group. Body mass index (BMI) was significantly lower in the OCD group, but BDNF levels were not found to correlate with BMI. Sixty four percent of patients had comorbid depression and 
Table 2 | Excluded studies.

\begin{tabular}{ll}
\hline Author & Reason for exclusion \\
\hline $\begin{array}{l}\text { Grassi-Oliveira } \\
\text { et al., 2008 }\end{array}$ & $\begin{array}{l}\text { MDD patients with and without childhood physical } \\
\text { neglect; PTSD assessed and severity of symptoms } \\
\text { correlated with BDNF levels } \\
\text { Hauck et al., 2008 }\end{array}$ \\
$\begin{array}{l}\text { Case reports } \\
\text { Kauer-Sant'Anna }\end{array}$ & $\begin{array}{l}\text { Bipolar patients with and without lifetime trauma } \\
\text { ex al., 2007 }\end{array}$ \\
Kobayashi et al., & BDNF assessed post treatment only \\
2005 & \\
Yoshimura et al., & Case reports \\
2006 &
\end{tabular}

44\% a comorbid anxiety disorder (PTSD: 24\%; PD: 24\%; SAD: 20\%; GAD: 16\%; AGP: 8\%). In addition, $8 \%$ had skin-picking disorder and $4 \%$ body dysmorphic disorder. Serum BDNF levels were significantly lower in the OCD group compared to controls $(0.0470 \pm 0.038 \mathrm{pg} / \mu \mathrm{g}$ vs. $0.747 \pm 0.060 \mathrm{pg} / \mu \mathrm{g}: p<0.001)$. Within the patient group, sexual/ religious symptom content, chronic course of symptoms and the presence of depression or $\mathrm{SAD}$ resulted in elevated $\mathrm{BDNF}$ levels compared to those without these features.

Maina et al. (2010) assessed serum BDNF levels in 24 medication-free OCD outpatients with no recent psychological stressors, and in 24 age- and gender-matched healthy controls. The following exclusion criteria were considered: current or previous diagnosis of organic mental disorder, schizophrenia, or other psychotic disorders, bipolar disorders, substance-related disorders; current diagnosis of depressive disorder and a maximum total score of 7 on the Hamilton Depression Rating Scale 17-item (HAM-D-17); uncontrolled or serious medical condition; any current or past psychopharmacological treatment; any severe stressful event within the year prior to inclusion. The mean ages of patients and controls were $37.7 \pm 12.2$ years and $38.2 \pm$ 10.6 years, respectively, and $38 \%$ of each group was female. The case-control study was conducted in Italy and was crosssectional in design. BDNF levels were significantly decreased in the OCD group compared to controls $(36900 \pm 6420 \mathrm{pg} / \mathrm{ml}$ vs. $41590 \pm 7820 \mathrm{pg} / \mathrm{ml} ; p=0.043)$. BDNF levels were not correlated with any clinical characteristic assessed, but there was a trend for lower BDNF levels in patients with a history of major depression $(p=0.09)$.

Wang et al. (2011) assessed plasma BDNF in 22 medication free (27\% female) and 52 drug-treated (36\% female) outpatients with OCD and 63 age- and gender-matched controls (48\% female), in China. This, too, was a cross-sectional, casecontrolled study. Individuals were excluded if they met any other DSM-IV axis I diagnosis, including lifetime history of depression; had a Hamilton Depression Rating Scale (HAMD, 17-item) score >7 (Hamilton, 1960); had any prior or current suicide attempts; were pregnant or lactating; or were in physical health such that they could not complete the study. BDNF concentrations differed significantly between patients and controls with both medication free $(1970 \pm 1800 \mathrm{pg} / \mathrm{ml}, p=0.00)$ and drug treated $(1980 \pm 1540 \mathrm{pg} / \mathrm{ml}, p=0.00)$ OCD patients having lower levels than controls $(4090 \pm 2000 \mathrm{pg} / \mathrm{ml})$. There was no significant difference in BDNF concentrations between medication-free and drug-treated patients, but females in the medication-free group had lower BDNF levels than males in the same group $(p=0.04)$. OCD patients tended to be younger than controls and length of illness in drug treated patients was higher than in medication-free patients. For the purposes of this review, we combined the medication-free and drug treated OCD groups to get a combined BDNF mean of 1980 $\pm 1590 \mathrm{pg} / \mathrm{ml}$.

One interventional study assessed BDNF levels in patients with Panic Disorder and one in a combined group of anxiety disorder patients. Strohle et al. (2010) studied 12 medication-free outpatients with PD (10 with agoraphobia) and 12 age- and gendermatched controls in the German population. Any participants with a comorbid Axis I disorder and using antidepressants were excluded from the study. Seventy-five percent of each group was female. Patients were found to have low depression and moderate anxiety levels. Serum BDNF levels were assessed prior to and post $30 \mathrm{~min}$ of exercise or quiet rest. Patients with panic disorder had significantly reduced serum BDNF levels compared to controls before rest or exercise $(p=0.003)$. For the purpose of this review we used the baseline assessments provided to us by the authors and combined these to get a combined BDNF mean of $2700.2 \pm 4184.9 \mathrm{pg} / \mathrm{ml}$ for patients and $9700.45 \pm 7291.15 \mathrm{pg} / \mathrm{ml}$ for controls.

Molendijk et al. (2011a) reported on a cross sectional analysis of a longitudinal study, in which serum BDNF levels were assessed in a cohort of 393 medication-free anxiety disorder patients and 382 healthy controls. Exclusion criteria included comorbid MDD and psychotropic medication use. The study took place in the Netherlands and participants were recruited from mental health care services, primary health care services and the general population. Sixty-seven percent of patients and $62 \%$ of controls were female. The patient group comprised participants with Agoraphobia, GAD, PD, SAD, or a combination of these disorders. All were currently free of current depression but $45 \%$ has a history of past depression. Controls were free of lifetime mood and anxiety disorders and not at high risk for these disorders. On average, patients were younger, had fewer years of education, and were more likely to smoke and/ or use alcohol, but these variables were controlled for in the analyses. BDNF concentrations did not differ significantly between patients and controls $(9310 \pm 3380 \mathrm{pg} / \mathrm{ml}$ vs. $9490 \pm 3180 \mathrm{pg} / \mathrm{ml}, p=0.49)$. There were also no statistically significant differences in BDNF levels between each type of anxiety disorder vs. controls. However, female patients had lower BDNF levels than female controls and male patients.

\section{Excluded studies}

Five studies were excluded from the review. Two studies were excluded as they were case reports on serum BDNF levels (Yoshimura et al., 2006; Hauck et al., 2008) and one only assessed serum BDNF levels after medication treatment (Kobayashi et al., 2005). Another study assessed serum BDNF levels in patients with bipolar disorder and compared those with and without trauma exposure (Kauer-Sant'Anna et al., 2007). Although the 
authors report that participants with and without PTSD did not differ with regards to BDNF levels, not enough information was available to enable us to compare the two groups. The final study compared patients with major depressive disorder with and without childhood physical neglect (Grassi-Oliveira et al., 2008). Although PTSD was assessed for, comparisons with regards to plasma BDNF were not reported, and again not enough information was available for us to compare the groups.

\section{ASSOCIATION OF BDNF WITH ANXIETY DISORDERS}

The forest plot of included studies is presented in Table 3. Six of the eight studies included showed differences in BDNF protein levels between participants with an anxiety disorder and participants without. In five of these reports (Dell'Osso et al., 2009; Maina et al., 2010; Strohle et al., 2010; dos Santos et al., 2011; Wang et al., 2011), BDNF levels (both serum and plasma) in patients with an anxiety disorder were lower than in participants without an anxiety disorder, with effect sizes ranging from moderate to large. The finding of one report (Hauck et al., 2010) was, however, in the opposite direction, with patients having significantly higher BDNF levels than controls. Effect size in this study was large. In the final 2 studies (Bonne et al., 2011; Molendijk et al., 2011a) participants with an anxiety disorder did not differ from those without with regards to BDNF levels. When results of all studies were combined, there was a significant difference between groups with lower BDNF levels in patients with an anxiety disorder [SMD $=-0.94$ $(-1.75,-0.12) ; z=2.25, p=0.02]$. There was, however, also significant statistical heterogeneity across studies $\left(p<0.01 ; I^{2}=\right.$ 95\%).

Sensitivity analyses of serum studies (Table 4) yielded a different result, although there was a trend toward significance for lower BDNF levels in the anxiety disorders [SMD $=-1.06$ $(-2.27,0.16) ; z=1.70, p=0.09]$. Sensitivity analyses of plasma studies alone did, however, result in significant group differences $[\mathrm{SMD}=-1.31(-1.69,-0.92) ; z=1.70, p<0.01]$, with little heterogeneity present $\left(p>0.05 ; I^{2}=0\right)$ (Table 5$)$.

When we looked at the PTSD studies only, we found no significant effect $[\mathrm{SMD}=-0.05(-1.66,1.75) ; z=0.06, p=0.95]$ (Table 6). Sub-analyses of OCD studies, however, did show a significant effect $[\mathrm{SMD}=-2.33(-4.21,-0.45) ; z=2.43, p=$

Table 3 | Meta-regression analysis of BDNF in anxiety disorders.

\begin{tabular}{|c|c|c|c|c|c|c|c|c|c|c|}
\hline \multirow[t]{2}{*}{ Study or subgroup } & \multicolumn{3}{|c|}{ Anxiety } & \multicolumn{3}{|c|}{ Control } & \multirow[t]{2}{*}{ Weight \% } & \multirow{2}{*}{$\begin{array}{l}\text { Std. mean difference } \\
\text { IV, random, } 95 \% \mathrm{CI}\end{array}$} & \multirow{2}{*}{\multicolumn{2}{|c|}{$\begin{array}{l}\text { Std. mean difference } \\
\text { IV, random, } 95 \% \mathrm{CI}\end{array}$}} \\
\hline & Mean & SD & Total & Mean & SD & Total & & & & \\
\hline Bonne et al., 2011 & 1 & 0.52 & 16 & 0.83 & 0.44 & 11 & 12.3 & $0.34[-0.44,1.11]$ & -1 & \\
\hline Dell'Osso et al., 2009 & 5300 & 1100 & 18 & 7400 & 1500 & 18 & 12.3 & $-1.56[-2.32,-0.80]$ & $\rightarrow$ & \\
\hline dos Santos et al., 2011 & 0.47 & 0.038 & 25 & 0.75 & 0.06 & 25 & 10.4 & $-5.49[-6.74,-4.24]$ & -1 & $=$ \\
\hline Hauck et al., 2010 & 0.49 & 0.21 & 34 & 0.25 & 0.14 & 34 & 13.1 & $1.33[0.80,1.86]$ & & \\
\hline Maina et al., 2010 & 36,900 & 6420 & 24 & 41,590 & 7820 & 24 & 12.9 & $-0.64[-1.23,-0.06]$ & $=$ & \\
\hline Molendijk et al., 2011a & 9310 & 3380 & 393 & 9490 & 3180 & 382 & 13.8 & $-0.05[-0.20,0.09]$ & & \\
\hline Strohle et al., 2010 & 2700.2 & 4184.9 & 12 & 9700.45 & 7291.15 & 12 & 11.9 & $-1.14[-2.01,-0.26]$ & & \\
\hline Wang et al., 2011 & 1980 & 1590 & 74 & 4090 & 2000 & 32 & 13.3 & $-1.22[-1.66,-0.77]$ & Favours control & Favours anxiety \\
\hline Total (95\% Cl) & & & 596 & & & 538 & 100.0 & $-0.94[-1.75,-0.12]$ & & \\
\hline
\end{tabular}

Heterogeneity: $\tau^{2}=1.26 ; \chi^{2}=145.79, d f=7(P<0.00001) ; 1^{2}=95 \%$.

Test for overall effect: $Z=2.25(P=0.02)$.

Table 4 | Sensitivity analysis: studies using serum.

\begin{tabular}{|c|c|c|c|c|c|c|c|c|c|}
\hline \multirow[t]{2}{*}{ Study or subgroup } & \multicolumn{3}{|c|}{ Anxiety } & \multicolumn{3}{|c|}{ Control } & \multirow[t]{2}{*}{ Weight \% } & \multirow{2}{*}{$\begin{array}{l}\text { Std. mean difference } \\
\text { IV, random, } 95 \% \mathrm{CI}\end{array}$} & \multirow{2}{*}{$\begin{array}{l}\text { Std. mean difference } \\
\text { IV, random, } 95 \% \mathrm{CI}\end{array}$} \\
\hline & Mean & SD & Total & Mean & SD & Total & & & \\
\hline Bonne et al., 2011 & 1 & 0.52 & 16 & 0.83 & 0.44 & 11 & 0.0 & $0.34[-0.44,1.11]$ & \\
\hline Dell'Osso et al., 2009 & 5300 & 1100 & 18 & 7400 & 1500 & 18 & 0.0 & $-1.56[-2.32,-0.80]$ & $\rightarrow-$ \\
\hline dos Santos et al., 2011 & 0.47 & 0.038 & 25 & 0.75 & 0.06 & 25 & 17.6 & $-5.49[-6.74,-4.24]$ & $=$ \\
\hline Hauck et al., 2010 & 0.49 & 0.21 & 34 & 0.25 & 0.14 & 34 & 20.8 & $1.33[0.80,1.86]$ & 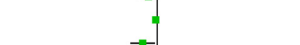 \\
\hline Maina et al., 2010 & 36,900 & 6420 & 24 & 41,590 & 7820 & 24 & 20.6 & $-0.64[-1.23,-0.06]$ & \\
\hline Molendijk et al., 2011a & 9,310 & 3380 & 393 & 9490 & 3180 & 382 & 21.6 & $-0.05[-0.20,0.09]$ & \\
\hline Strohle et al., 2010 & 2700.2 & 4184.9 & 12 & 9700.45 & 7291.15 & 12 & 19.4 & $-1.14[-2.01,-0.26]$ & $\begin{array}{ccccc}1 & 1 & & 1 & 1 \\
-10 & -5 & 0 & 5 & 10\end{array}$ \\
\hline Wang et al., 2011 & 1980 & 1590 & 74 & 4090 & 2000 & 32 & 0.0 & $-1.22[-1.66,-0.77]$ & Favours control Favours anxiety \\
\hline Total $(95 \% \mathrm{Cl})$ & & & 488 & & & 477 & 100.0 & $-1.06[-2.27,0.16]$ & \\
\hline
\end{tabular}

Heterogeneity: $\tau^{2}=1.77 ; \chi^{2}=108.59, d f=(P<0.00001) ; 1^{2}=96 \%$.

Test for overall effect: $Z=1.70(P=0.09)$. 
Table 5 | Sensitivity analysis: studies using plasma.

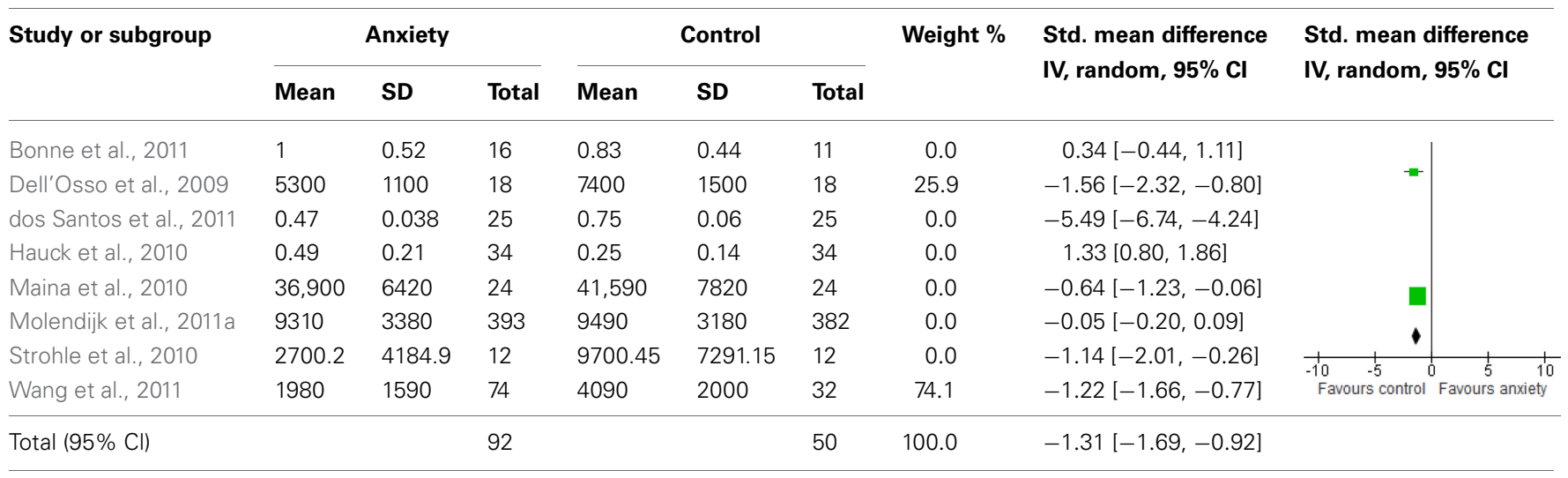

Heterogeneity: $\tau^{2}=0.00 ; \chi^{2}=0.59, d f=1(P=0.44) ; 1^{2}=0 \%$.

Test for overall effect: $Z=6.65(P<0.00001)$.

Table 6 | Subgroup analysis: PTSD studies.

\begin{tabular}{|c|c|c|c|c|c|c|c|c|c|}
\hline \multirow[t]{2}{*}{ Study or subgroup } & \multicolumn{3}{|c|}{ Anxiety } & \multicolumn{3}{|c|}{ Control } & \multirow[t]{2}{*}{ Weight \% } & \multirow{2}{*}{$\begin{array}{l}\text { Std. mean difference } \\
\text { IV, random, } 95 \% \mathrm{CI}\end{array}$} & \multirow{2}{*}{$\begin{array}{l}\text { Std. mean difference } \\
\text { IV, random, } 95 \% \mathrm{CI}\end{array}$} \\
\hline & Mean & SD & Total & Mean & SD & Total & & & \\
\hline Dell'Osso et al., 2009 & 5300 & 1100 & 18 & 7400 & 1500 & 18 & 33.0 & $-1.56[-2.32,-0.80]$ & \multirow[t]{2}{*}{-} \\
\hline dos Santos et al., 2011 & 0.47 & 0.038 & 25 & 0.75 & 0.06 & 25 & 0.0 & $-5.49[-6.74,-4.24]$ & \\
\hline Hauck et al., 2010 & 0.49 & 0.21 & 34 & 0.25 & 0.14 & 34 & 34.1 & $1.33[0.80,1.86]$ & \\
\hline Molendijk et al., 2011a & 9310 & 3380 & 393 & 9490 & 3180 & 382 & 0.0 & $-0.05[-0.20,0.09]$ & \\
\hline Strohle et al., 2010 & 2700.2 & 4184.9 & 12 & 9700.45 & 7291.15 & 12 & 0.0 & $-1.14[-2.01,-0.26]$ & \multirow{2}{*}{$\begin{array}{ccccc} & 1 & 1 & 1 & 1 \\
-10 & -5 & 0 & 5 & 10 \\
\text { Favours control } & \text { Favours anxiety }\end{array}$} \\
\hline Wang et al., 2011 & 1980 & 1590 & 74 & 4090 & 2000 & 32 & 0.0 & $-1.22[-1.66,-0.77]$ & \\
\hline Total $(95 \% \mathrm{Cl})$ & & & 68 & & & 63 & 100.0 & $0.05[1.66,1.75]$ & \\
\hline
\end{tabular}

Heterogeneity: $\tau^{2}=2.15 ; \chi^{2}=37.69, d f=2(P<0.00001) ; 1^{2}=95 \%$.

Test for overall effect: $Z=0.06(P=0.95)$.

0.02] (Table 7). Heterogeneity was high in both these analyses. Taking into account the significant effect in studies of OCD, we re-ran the analyses, excluding studies of OCD and found no significant effect $[\mathrm{SMD}=0.18(-1.00,0.64) ; z=0.42, p=0.67]$ (Table 8).

\section{DISCUSSION}

We conducted a comprehensive search to identify studies related to our research question and believe that our review gives the most comprehensive overview of BDNF in anxiety disorders to date. We used systematic methods to reduce bias in the identification of studies, data extraction and synthesis, and appraisal of study quality. Our initial results suggested that BDNF levels differ between individuals with any anxiety disorder compared to those without, with levels being lower in those with an anxiety disorder. This was, however, dependent on the source of BDNF protein. Studies using plasma samples found a significant effect, whereas studies in serum showed only a trend toward significance.

The discrepancies between plasma and serum findings may be attributable to differences in the constitution of plasma and serum, which consequently represent separate pools of physiological material (D'Sa et al., 2012). Indeed, a study in depressed patients suggests that plasma BDNF may be statedependent marker while serum BDNF may be a trait marker; in the aforementioned study antidepressants normalized plasma BDNF levels only, in line with clinical improvement, and serum BDNF levels remain unchanged (Piccinni et al., 2008). Peripheral BDNF is largely stored in platelets and is released from activated platelets to serum during the clotting process, explaining the lower concentration of BDNF in plasma compared to serum (Rosenfeld et al., 1995; Radka et al., 1996). Further, differences in platelet functioning, either by their ability to release BDNF or sequester BDNF from blood, may result in differences between serum and plasma BDNF levels (Bus et al., 2011). There has been much debate over whether plasma or serum levels are an appropriate proxy for brain BDNF concentrations, with some authors noting that results for serum BDNF levels cannot be generalized to studies of BDNF in plasma or platelets (Bus et al., 2011).

Owing to the paucity of eligible studies, subgroup analyses of the different anxiety disorders were limited to PTSD and OCD studies. The PTSD subgroup analysis did not reveal any group differences in BDNF levels, however, the OCD analyses did find 
Table 7 | Subgroup analysis: OCD studies.

\begin{tabular}{|c|c|c|c|c|c|c|c|c|c|}
\hline \multirow[t]{2}{*}{ Study or subgroup } & \multicolumn{3}{|c|}{ Anxiety } & \multicolumn{3}{|c|}{ Control } & \multirow[t]{2}{*}{ Weight \% } & \multirow{2}{*}{$\begin{array}{l}\text { Std. mean difference } \\
\text { IV, random, } 95 \% \mathrm{Cl}\end{array}$} & \multirow{2}{*}{$\begin{array}{l}\text { Std. mean difference } \\
\text { IV, random, } 95 \% \mathrm{Cl}\end{array}$} \\
\hline & Mean & SD & Total & Mean & SD & Total & & & \\
\hline Bonne et al., 2011 & 1 & 0.52 & 16 & 0.83 & 0.44 & 11 & 0.0 & $0.34[-0.44,1.11]$ & \\
\hline Dell'Osso et al., 2009 & 5300 & 1100 & 18 & 7400 & 1500 & 18 & 0.0 & $-1.56[-2.32,-0.80]$ & $\rightarrow-$ \\
\hline dos Santos et al., 2011 & 0.47 & 0.038 & 25 & 0.75 & 0.06 & 25 & 30.7 & $-5.49[-6.74,-4.24]$ & \\
\hline Hauck et al., 2010 & 0.49 & 0.21 & 34 & 0.25 & 0.14 & 34 & 0.0 & $1.33[0.80,1.86]$ & \\
\hline Maina et al., 2010 & 36,900 & 6420 & 24 & 41,590 & 7820 & 24 & 34.4 & $-0.64[-1.23,-0.06]$ & $=$ \\
\hline Molendijk et al., 2011a & 9310 & 3380 & 393 & 9490 & 3180 & 382 & 0.0 & $-0.05[-0.20,0.09]$ & \\
\hline Strohle et al., 2010 & 2700.2 & 4184.9 & 12 & 9700.45 & 7291.15 & 12 & 0.0 & $-1.14[-2.01,-0.26]$ & \begin{tabular}{ll|lll}
1 & 1 & & & 1 \\
-10 & -5 & 0 & 5 & 10
\end{tabular} \\
\hline Wang et al., 2011 & 1980 & 1590 & 74 & 4090 & 2000 & 32 & 34.9 & $-1.22[-1.66,-0.77]$ & Favours control Favours anxiety \\
\hline Total (95\% Cl) & & & 123 & & & 81 & 100.0 & $-2.33[4.21,-045]$ & \\
\hline
\end{tabular}

Heterogeneity: $\tau^{2}=2.59 ; \chi^{2}=48.06, d f=2(P<0.00001) ; 1^{2}=96 \%$.

Test for overall effect: $Z=2.43(P=0.02)$.

Table 8 | Meta-regression analysis with OCD studies excluded.

\begin{tabular}{|c|c|c|c|c|c|c|c|c|c|}
\hline \multirow[t]{2}{*}{ Study or subgroup } & \multicolumn{3}{|c|}{ Anxiety } & \multicolumn{3}{|c|}{ Control } & \multirow[t]{2}{*}{ Weight \% } & \multirow{2}{*}{$\begin{array}{l}\text { Std. mean difference } \\
\text { IV, random, } 95 \% \mathrm{Cl}\end{array}$} & \multirow{2}{*}{$\begin{array}{l}\text { Std. mean difference } \\
\text { IV, random, } 95 \% \mathrm{Cl}\end{array}$} \\
\hline & Mean & SD & Total & Mean & SD & Total & & & \\
\hline Bonne et al., 2011 & 1 & 0.52 & 16 & 0.83 & 0.44 & 11 & 19.0 & $0.34[-0.44,1.11]$ & \\
\hline Dell'Osso et al., 2009 & 5300 & 1100 & 18 & 7400 & 1500 & 18 & 19.2 & $-1.56[-2.32,-0.80]$ & \multirow[t]{2}{*}{$\rightarrow$} \\
\hline dos Santos et al., 2011 & 0.47 & 0.038 & 25 & 0.75 & 0.06 & 25 & 0.0 & $-5.49[-6.74,-4.24]$ & \\
\hline Hauck et al., 2010 & 0.49 & 0.21 & 34 & 0.25 & 0.14 & 34 & 20.9 & $1.33[0.80,1.86]$ & 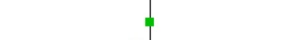 \\
\hline Maina et al., 2010 & 36,900 & 6420 & 24 & 41,590 & 7820 & 24 & 0.0 & $-0.64[-1.23,-0.06]$ & \\
\hline Molendijk et al., 2011a & 9310 & 3380 & 393 & 9490 & 3180 & 382 & 22.7 & $-0.05[-0.20,0.09]$ & \\
\hline Strohle et al., 2010 & 2700.2 & 4184.9 & 12 & 9700.45 & 7291.15 & 12 & 18.2 & $-1.14[-2.01,-0.26]$ & \multirow{2}{*}{$\begin{array}{ccccc}-10 & -5 & 0 & 5 & 10 \\
- & \text { Favours control } & \text { Favours anxiety }\end{array}$} \\
\hline Wang et al., 2011 & 1980 & 1590 & 74 & 4090 & 2000 & 32 & 0.0 & $-1.22[-1.66,-0.77]$ & \\
\hline Total (95\% Cl) & & & 473 & & & 457 & 100.0 & $0.05[1.66,1.75]$ & \\
\hline
\end{tabular}

Heterogeneity: $\tau^{2}=0.76 ; \chi^{2}=48.31, d f=4(P<0.00001) ; 1^{2}=92 \%$.

Test for overall effect: $Z=0.42(P=0.67)$.

significantly reduced BDNF levels in patients with OCD compared to controls. While only plasma studies in PTSD found differences in the general direction of the meta-analysis, two serum studies found these differences in OCD. Although the dearth of eligible studies did not permit further analyses to ascertain whether differences are attributable to protein source, this does suggest a stronger biological effect of BDNF in OCD. Of note, when studies of OCD were excluded from the meta-analysis, group differences were no longer significant for the other anxiety disorders. This effect, therefore, seems to be restricted to OCD.

To date, the majority of studies examining BDNF in patients with anxiety disorders have focused on genetic associations between the Val66Met polymorphism and the development of anxiety, and have reported conflicting results (Alonso et al., 2008; Hemmings et al., 2008; Wendland et al., 2008). Results of this review and meta-analyses, focusing on BDNF protein levels from serum, plasma and CSF, indicate that lowered levels of BDNF in participants with anxiety disorders in comparison to controls is due to significantly lowered levels of BDNF in patients with OCD. The variation in the direction of association, or lack of association, between individual studies may represent differences in BDNF sampling and analysis (whether serum, plasma or CSF BDNF levels were measured, storage conditions, type of assays used, etc.), or underlying genetic differences between populations. Age, BMI, gender and sex hormones, smoking, alcohol use, physical activity, time of day of blood draw, and number of months of storage have also been found to play a role in BDNF levels in both healthy adults and in those with a psychiatric diagnosis (Lommatzsch et al., 2005; Trajkovska et al., 2007; Ziegenhorn et al., 2007; Li et al., 2009; Bus et al., 2011; Maina et al., 2010; Ozan et al., 2010; Molendijk et al., 2011a).

It is important to bear in mind that these findings are largely based on the assumption that peripheral BDNF levels mirror the amount of BDNF in the brain, and this may be a limitation since there are other potential sources of BDNF (Karege et al., 2002b). The brain may be a major contributor to circulating blood levels (Rasmussen et al., 2009), and BDNF has been found to cross the blood-brain barrier (Pan et al., 1998). It is therefore conceivable that peripheral BDNF levels may comprise BDNF that has originated in CNS neurons (Lommatzsch et al., 2005). To this end, a number of recent animal studies have documented a correlation between levels of BDNF in blood and brain 
(Karege et al., 2002a; Sartorius et al., 2009; Klein et al., 2011), although not all results have been consistent (Elfving et al., 2010; Lanz et al., 2012)

BDNF is synthesized as a precursor protein, known as proBDNF, which is subsequently cleaved to yield mature BDNF. Although it was initially thought that proBDNF was inactive, it has recently been found to play a role in a number of physiological functions, by binding to the pan-neurotrophin receptor p75 (Pang et al., 2004). In fact, the yin-yang neurotrophic theory posits that proBDNF and mature BDNF exhibit opposing effects on neuroplasticity, with proBDNF initiating apoptotic signaling cascades, whilst mature BDNF initiates cell survival pathways by binding to the tyrosine kinase $\mathrm{B}$ receptor (TrkB) (Lu et al., 2005). It may thus be beneficial to investigate the levels of proBDNF and mature BDNF separately; however, studies included in the present review utilized ELISAs which were not able to discriminate between the two forms of BDNF.

A number of other limitations deserve mention. First, since anxiety disorders and depression are highly comorbid and there is evidence for lower BDNF in depression, the inclusion of patients with depression in some of the studies may partially account for the reduced plasma BDNF levels in the patient sample. This, however, does not appear to be the case here as four of the five included studies (Hauck et al., 2010; Maina et al., 2010; Bonne et al., 2011; Wang et al., 2011) found that the presence of past and/ or current depression did not have a significant effect, while the fifth study found BDNF levels

\section{REFERENCES}

Alonso, P., Gratacòs, M., Menchón, J., Saiz-Ruiz, J., Segalàs, C., Baca-García, E., et al. (2008). Extensive genotyping of the BDNF and NTRK2 genes define protective haplotypes against obsessive-compulsive disorder. Biol. Psychiatry 63, 619-628. doi: 10.1016/j.biopsych.2007.06.020

Amorin, P. (2000). Mini international neuropsychiatric interview (MINI): validação de entrevista breve para diagnóstico de transtornos mentais. Rev. Bras. Psiquiatr. 22, 106-115. doi: 10.1590/S151644462000000300003

Aydemir, C., Yalcin, E. S., Aksaray, S., Kisa, C., Yildirim, S. G., Uzbay, T., et al. (2006). Brain-derived neurotrophic factor (BDNF) changes in the serum of depressed women. Prog. Neuropsychopharmacol. Biol. Psychiatry 30, 1256-1260.

Bandelow, B. (1997). Assessing the efficacy of treatment for panic disorder and agoraphobia. II. The panic and agoraphobia scale. Int. Clin. Psychopharmacol. 10, 83-93. doi: 10.1097/00004850-19950600000004

Blake, D. D., Weathers, F. W., Nagy,

L. M., and Kaloupek, D. G.
(1995). The development of a clinician-administered PTSD scale. J. Trauma. Stress 8, 75-90. doi: 10.1002/jts. 2490080106

Bocchio-Chiavetto, L., Bagnardi, V., Zanardini, R., Molteni, R., Nielsen, M. G., Placentino, A., et al. (2010). Serum and plasma BDNF levels in major depression: a replication study and meta-analyses. World J. Biol. Psychiatry 11, 763-773. doi: 10.3109/15622971003611319

Bonne, O., Gill, J. M., Luckenbaugh, D. A., Collins, C., Owens, M. J., Alesci, S., et al. (2011). Corticotropinreleasing factor, interleukin-6, brain-derived neurotrophic factor, insulin-like growth factor-1, and substance $\mathrm{p}$ in the cerebrospinal fluid of civialians with posttrauamtic stress disorder before and after treatment with paroxetine. J. Clin. Psychiatry 72, 1124-1128. doi: 10.4088/JCP.09m05106blu

Brunoni, A. R., Lopes, M., and Fregni, F. (2008). A systematic review and meta-analysis of clinical studies on major depression and BDNF levels: implications for the role of neuroplasticity in depression. Int. J. Neuropsychopharmacol. 11, 1169-1180. doi: 10.1017/ S1461145708009309

were in fact elevated in patients with MDD (dos Santos et al., 2011).

Second, two studies contained in the meta-regression included patients on psychotropic medication treatment (Hauck et al., 2010; Wang et al., 2011) and previous studies that have examined the relationship of BDNF and psychotropic medication use, (i.e., serotonin reuptake inhibitors), have shown that the latter medications increase peripheral BDNF levels in humans (Piccinni et al., 2008; Matrisciano et al., 2009). However, it should be noted that in both studies medication did not appear to have a significant effect on outcomes. Third, although the quality of included studies was judged overall to be adequate, the findings in the present study need to be interpreted with caution, given that not all studies reported on potential confounding variables and their adjustment in analyses. Further, meta-analytic data also need to be cautiously interpreted, given the substantial heterogeneity between studies.

In summary, although there is evidence for lower peripheral BDNF in anxiety disorders, this seems to result specifically from lower BDNF in OCD, rather than other anxiety disorders. However, given the paucity of studies and the relatively small number of participants in most, as well as the limitations noted above, the role of BDNF protein in anxiety disorders is still currently far from being understood. To this end, further evidence from large prospective studies is needed. In particular, studies that address the generalizability of serum and plasma samples, and the variable procedures that lead up to the measurement of peripheral BDNF are called for.

Bus, B. A. A., Molendijk, M. L., Penninx, B. J. W. H., Buitelaar, J. K., Kenis, G., Prickaerts, J., et al. (2011). Determinants of serum brain derived neurotrophic factor. Psychoneuroendocrinology 36, 228-239. doi: 10.1016/j.psyneuen. 2010.07.013

Carbone, D. L., and Handa, R. J. (2013). Sex and stress hormone influences on the expression and activity of brain-derived neurotrophic factor. Neuroscience 239, 295-303. doi: 10.1016/j.neuroscience.2012.10.073

Carola, V., Frazzetto, G., Pascucci, T., Audero, E., Puglisi-Allegra, S., Cabib, S., et al. (2008). Identifying molecular substrates in a mouse model of the serotonin transporter $\mathrm{x}$ environment risk factor for anxiety and depression. Biol. Psychiatry 63, 840-846. doi: 10.1016/j.biopsych.2007.08.013

Champagne, F., and Meaney, M. J. (2001). Like mother, like daughter: evidence for non-genomic transmission of parental behavior and stress responsivity. Prog. Brain Res. 133, 287-302. doi: 10.1016/S00796123(01)33022-4

Chen, Z.-Y., Jing, D., Bath, K. G., Ieraci, A., Khan, T., Siao, C.-J., et al. (2006). Genetic variant BDNF (val 66 met) polymorphism alters anxiety-related behavior. Science 314, 140-143.

David, D. J., Samuels, B. A., Rainer, Q., Wang, J.-W., Marsteller, D., Mendez, I., et al. (2009). Neurogenesisdependent and-independent effects of fluoxetine in an animal model of anxiety/depression. Neuron 62, 479-493.

Davidson, J. R., Malik, M. A., and Travers, J. (1997). Structured interview for PTSD (SIP): psychometric validation for DSM-IV criteria. Depress. Anxiety 5, 127-9.

Dell'Osso, L., Carmassi, C., Del Debbio, A., Dell'Osso, M. C., Bianchi, C., da Pozzo, E., et al. (2009). Brainderived neurotrophic factor plasma levels in patients suffering from post-traumatic stress disorder. Prog. Neuropsychopharmacol. Biol. Psychiatry 33, 899-902. doi: 10.1016/j.pnpbp.2009.04.018

dos Santos, I. M., Ciulla, L., Braga, D., Ceresér, K. M., Gama, C. S., Kapczinski, F., et al. (2011). Symptom dimensional approach and BDNF in unmedicated obsessive-compulsive patients: an exploratory study. CNS Spectr. 16, 179-189. doi: $10.1017 / \mathrm{S} 1092852912000363$ 
D'Sa, C., Dileone, R. J., Anderson, G. M., and Sinha, R. (2012). Serum and plasma brain-derived.neurotrophic factor (BDNF) in abstinent alcoholics and social drinkers. Alcohol $46,253-259$.

Duman, R. S. (2002) Synaptic plasticity and mood disorders. Mol. Psychiatry 7, S29-S34.

Duman, R. S., and Monteggia, L. M. (2006). A neurotrophic model for stress-related mood disorders. Biol. Psychiatry 59, 1116-1127. doi: 10.1016/j.biopsych.2006.02.013

Dunham, J. S., Deakin, J. F., Miyajima, F., Payton, A., and Toro, C. T. (2009). Expression of hippocampal brain-derived neurotrophic factor and its receptors in Stanley consortium brains. J. Psychiatr. Res. 43, 1175-1184. doi: 10.1016/j.jpsychires.2009.03.008

Duval, F., Crocq, M. A., Guillon, M. S., Mokrani, M. C., Monreal, J., Bailey, P., et al. (2004). Increased adrenocorticotropin suppression following dexamethasone administration in sexually abused adolescents with posttraumatic stress disorder. Psychoneuroendocrinology 29, 1281-1289. doi: 10.1016/j.psyneuen.2004.03.006

Elfving, B., Plougmann, P. H., and Wegener, G. (2010). Detection of brain-derived neurotrophic factor (BDNF) in rat blood and brain preparations using ELISA: pitfalls and solutions. J. Neurosci. Methods 187, 73-77. doi: 10.1016/j.jneumeth.2009.12.017

First, M. B., Gibbon, M., Spitzer, R. L., Williams, J. B. W., and Benjamin, L. S. (1997). Structured Clinical Interview for DSM-IV Disorders Axis II (SCID-II). Washington, DC: American Psychiatric Press.

First, M. B., Spitzer, R. L., and Gibbon, M. (1996). Structured Clinical Interview for DSM-IV Axis I Disorders, Research Version, Patient Edition, Version 2.0 (SCID-I/P). New York, NY: New York State Psychiatric Institute, Biometrics Research.

First, M. B., Spitzer, R. L., Williams, J. B. W., and Gibbon, M. (1995). Structured Clinical Interview for DSMIV-Patient Edition (SCID$P$ ). Washington, DC: American Psychiatric Press.

Goodman, W. K., Price, L. H., Rasmussen, S. A., Mazure, C., Fleischmann, R. L., Hill, C. L., et al. (1989). The yale-brown obsessive-compulsive scale, I: development, use and reliability. Arch. Gen. Psychiatry 46, 1006-1011. doi: 10.1001/archpsyc. 1989.01810110048007
Govindarajan, A., Rao, B. S. S., Nair, D., Trinh, M., Mawjee, N., Tonegawa, S., et al. (2006). Transgenic brainderived neurotrophic expression causes both anxiogenic and antidepressant effects. Proc. Natl. Acad. Sci. U.S.A. 103,13208-13213. doi: 10.1073/pnas.0605180103

Grassi-Oliveira, R., Stein, L. M., Lopes, R. P., Teixeira, A. L., and Bauer, M. E. (2008). Low plasma brain-derived neurotrophic factor and childhood physical neglect are associated with verbal memory impairment in major depression-a preliminary report. Biol. Psychiatry 64, 281-285. doi: 10.1016/j.biopsych.2008.02.023

Hamilton, M. (1960). A rating scale for depression. J. Neurol. Neurosurg. Psychiatry 23, 56-62. doi: 10.1136/jnnp.23.1.56

Hartmann, M., Heumann, R., and Lessmann, V. (2001). Synaptic secretion of BDNF after high-frequency stimulation of glutamatergic synapses. EMBO J. 20, 5887-5897.

Hashimoto, K. (2010). Brain-derived neurotrophic factor as a biomarker for mood disorders: an historical overview and future directions. Psychiatry Clin. Neurosci. 64, 341-357.

Hauck, S., Gomes, F., Siveira Júnior Éde M., Almeida, E., Possa, M., and Ceitlin, L. H. F. (2008). Serum levels of brain-derived neurotrophic factor in acute and post-traumatic stress disorder: a case report study. Rev. Bras. Psiquiatr. 31, 48-51.

Hauck, S., Kapczinski, F., Roesler, R., de Moura Silveira, E. Jr., Magalhães, P. V., Kruel, L. R. P., et al. (2010). Serum brain-derived neurotrophic factor in patients with trauma psychopathology. Prog. Neuropsychopharmacol. Biol. Psychiatry 34, 459-462.

Hemmings, S. M., Kinnear, C. J., Van der Merwe, L., Lochner, C., Corfield, V. A., Moolman-Smook, J. C., et al., (2008). Investigating the role of the brain-derived neurotrophic factor (BDNF) val66met variant in obsessivecompulsive disorder (OCD). World J. Biol. Psychiatry 9, 126-134. doi: 10.1080/15622970701245003

Horowitz, M. J., Wilner, N., and Alvarez, W. (1979). Impact of event scale: a measure of subjective stress. Psychosom. Med. 41, 209-218.

Karege, F., Bondolfi, G., Gervasoni, N., Schwald, M., Aubry, J. M. and Bertschy, G. (2005). Low brain-derived neurotrophic factor (BDNF) levels in serum of depressed patients probably results from lowered platelet BDNF release unrelated to platelet reactivity. Biol. Psychiatry 57, 1068-1072. doi: 10.1016/j.biopsych.2005.01.008

Karege, F., Schwaldt, M., and Cisse, M. (2002a). Postnatal developmental profile of brain-derived neurotrophic factor in rat brain and platelets. Neurosci. Lett. 328 , 261-264.

Karege, F., Perret, H., Bondolfi, G., Schwald, M., Bertschv, G., and Aubrey, J. M. (2002b). Decreased serum brain-derived neurotrophic factor levels in major depressed patients. Psychol. Res. 109, 143-148.

Kauer-Sant'Anna, M., Tramontina, J., Andreazza, A. C., Cereser, K., da Costa, S., Santin, A., et al. (2007). Traumatic life events in bipolar disorder: impact on BDNF levels and psychopathology. Bipolar Disord. 9, 128-135. doi 10.1111/j.1399-5618.2007.00478.x

Kendler, K. S., Neale, M. C., Kessler, R. C., Heath, A. C., and Eaves, L. J. (1992). Major depressive disorder and generalized anxiety disorder. Same genes, (partly) different environments? Arch. Gen. Psychiatry 49,716-722.

Kendler, K. S., Walters, E. E., Neale, M. C., Kessler, R. C., Heath, A. C., and Eaves, L. J. (1995). The structure of the genetic and environmental risk factors for six major psychiatric disorders in women: phobia, generalized anxiety disorder, panic disorder, bulimia, major depression, and alcoholism. Arch. Gen. Psychiatry 52, 374-383. doi: 10.1001/arch psyc.1995.03950170048007

Kim, S. W., Dysken, M. W., and Kuskowski, M. (1990). The yalebrown obsessive-compulsive scale: a reliability and validity study. Psychiatry Res. 34, 99-106. doi 10.1016/0165-1781(90)90061-9

Klaassen, T., Klumperbeek, J., Deutz, N E., van Praag, H. M., and Griez, E. (1998). Effects of tryptophan depletion on anxiety and on panic provoked by carbon dioxide challenge. Psychiatry Res. 77, 167-174. doi 10.1016/S0165-1781(98)00004-3

Klein, A. B., Williamson, R., Santini, M. A., Clemmensen, C., Ettrup, A., Rios, M., et al. (2011). Blood BDNF concentrations reflect braintissue BDNF levels across species. Int. J. Neuropsychopharmacol. 14 347-353.

Kobayashi, K., Shimizu, E., Hashimoto, K., Mitsumori, M., Koike, K. Okamura, N., et al. (2005). Serum brain-derived neurotrophic factor (BDNF) levels in patients with panic disorder: as a biological predictor of response to group cognitive behavioral therapy. Prog. Neuropsychopharmacol. Biol. Psychiatry 29, 658-663.

Kurita, M., Nishino, S., Kato, M. Numata, Y., and Sato, T. (2012). Plasma brain-derived neurotrophic factor levels predict the clinical outcome of depression treatment in a naturalistic study. PLoS ONE 7:e39212. doi: 10.1371/journal.pone.0039212

Lang, U. E., Hellweg, R., Seifert, F., Schubert, F., and Gallinat, J. (2007). Correlation between serum brainderived neurotrophic factor level and an in vivo marker of cortical integrity. Biol. Psychiatry 62, 530-555. doi: 10.1016/j.biopsych.2007.01.002

Lanz, T. A., Bove, S. E., Pilsmaker, C. D., Mariga, A., Drummond, E. M., Cadelina, G. W., et al. (2012). Robust changes in expression of brain-derived neurotrophic factor (BDNF) mRNA and protein across the brain do not translate to detectable changes in BDNF levels in CSF or plasma. Biomarkers 17, 524-531. doi: 10.3109/1354750X.2012.694476

Li, G., Peskind, E. R., Millard, S. P., Chi, P., Sokal, I., Yu, C., et al. (2009). Cerebrospinal fluid concentration of brain-derived neurotrophic factor and cognitive function in non-demented subjects. PLoS ONE 4:e5424. doi: 10.1371/journal.pone.0005424

Lindsay, R. M., Wiegand, S. J., Altar, C. A., and DiStefano, P. S. (1994). Neurotrophic factors: from molecule to man. Trends Neurosci. 17, 182-190. doi: 10.1016/0166-2236(94)90099-X

Lommatzsch, M., Zingler, D., Schuhbaeck, K., Schloetcke, K., Zingler, C., Schuff-Werner, P., et al. (2005). The impact of age, weight and gender on BDNF levels in human platelets and plasma. Neurobiol. Aging 26, 115-123. doi: 10.1016/ j.neurobiolaging.2004.03.002

Lu, B., Pang, P. T., and Woo, N. H. (2005). The yin and yang of neurotrophin action. Nat. Rev. Neurosci. 6, 603-614. doi: 10.1038/nrn1726

Maina, G., Rosso, G., Zanardini, R., Bogetto, F., Gennarelli, M., and Bocchio-Chiavetto, L. (2010). Serum levels of brain-derived neurotrophic factor in drugnaïve obsessive-compulsive patients: a case-control study. J. Affect. Disord. 122, 174-178. doi: 10.1016/j.jad.2009.07.009

Manji, H. K., Quiroz, J. A., Sporn, J., Payne, J. L., Denicoff, K., Gray, N., et al. (2003). Enhancing neuronal 
plasticity and cellular resilience to develop novel, improved therapeutics for difficult-to-treat depression. Biol. Psychiatry 53, 707-742. doi: 10.1016/S0006-3223(03)i00117-3

Maron, E., Toru, I., Vasar, V., and Shlik, J. (2004). The effect of 5-hydroxy trypthophan on cholecystokinin-4-induced panic attacks in healthy volunteers. J. Psychopharmacol. 18, 194-199. doi: $10.1177 / 0269881104042619$

Matrisciano, F., Bonaccorso, S., Ricciardi, A., Scaccianoce, S., Panaccione, I., Wang, L., et al. (2009). Changes in BDNF serum levels in patients with major depression disorder (MDD) after 6 months treatment with sertraline, escitalopram, or venlafaxine. J. Psychiatr. Res. 43, 247-254. doi: 10.1016/j.jpsychires.2008.03.014

McEwen, B. S. (1998). Protective and damaging effects of stress mediators. N. Engl. J. Med. 338, 171-179. doi: 10.1056/NEJM199801153380307

McEwen, B. S., and Stellar, E. (1993). Stress and the individual: mechanisms leading to disease. Arch. Int. Med. 153, 2093-2101.

Molendijk, M. L., Bus, B. A. A., Spinhoven, P., Kaimatzoglou, A., Voshaar, R. C. O., Penninx, B. W. J. H., et al. (2012). A systematic review and meta-analysis on the association between BDNF val66met and hippocampal volumea genuine effect or a winners curse? Am. J. Med. Genet. 159B, 731-740.

Molendijk, M. L., Bus, B. A. A., Spinhoven, P., Penninx, B. W. J. H., Prickaerts, J., Oude Voshaar, R. C., et al. (2011a). Gender specific associations of serum levels of brain-derived neurotrophic factor in anxiety. World J. Biol. Psychiatry 13, 535-543. doi: 10.3109/15622975 .2011 .587892

Molendijk, M. L., Bus, B. A. A., Spinhoven, P., Penninx, B. J. W. H., Kenis, G., Prickaerts, J., et al. (2011b). Serum levels of brainderived neurotrophic factor in major depressive disorder: state and trait issues, clinical features, and pharmacological treatment. Mol. Psychiatry 16, 1088-1095.

Monteggia, L. M., Luikart, B., Barrot, M., Theobold, D., Malkovska, I., Nef, S., et al. (2007). Brain-derived neurotrophic factor conditional knockouts show gender differences in depression-related behaviors. Biol. Psychiatry 61, 187-197. doi: 10.1016/j.biopsych.2006.03.021

Ozan, E., Okur, H., Cagdas, E., Ekerd, O. D., Saffet Gonul, A., and Akarsu,
N. (2010). The effect of depression, BDNF gene val66met polymorphism and gender on serum BDNF levels. Brain Res. Bull. 81, 61-65.

Pan, W., Banks, W. A., Fasold, M. B., Bluth, J., and Kastin, A. J. (1998). Transport of brain-derived neurotrophic factor across the bloodbrain barrier. Neuropharmacology 37, 1553-1561. doi: 10.1016/S00283908(98)00141-5

Pang, P. T., Teng, H. K., Zaitsev, E., Woo, N. T., Sakata, K., Zhen, S., et al. (2004). Cleavage of proBDNF by $\mathrm{tPA} /$ plasmin is essential for long-term hippocampal plasticity. Science 306, 487-491. doi: 10.1126/science. 1100135

Piccinni, A., Marazziti, D., Catena, M., Domenici, L., Del Debbio, A., Bianchi, C., et al. (2008). Plasma and serum brain-derived neurotrophic factor (BDNF) in depressed patients during 1 year of antidepressant treatments. J. Affect. Disord. 105, 279-283. doi: 10.1016/j.jad.2007.05.005

Radka, S. F., Holst, P. A., Fritsche, M., and Atlar, C. A. (1996). Presence of brain-derived neurotrophic factor in brain and human and rat but not mouse serum detected by a sensitive and specific immunoassay. Brain Res. 709, 122-130.

Rasmussen, P., Brassard, P., Adser, H., Pedersen, M. V., Leick, L., Hart, E., et al. (2009). Evidence for a release of brain-derived neurotrophic factor from the brain during exercise. Exp. Physiol. 94, 1062-1069. doi: 10.1113/expphysiol.2009.048512

Rasmusson, A. M., Shi, L., and Duman, R. (2002). Downregulation of BDNF mRNA in the hippocampal dentate gyrus after re-exposure to cues previously associated with footshock. Neuropsychopharmacology 27, 133-142. doi: 10.1016/S0893133X(02)00286-5

Rosenfeld, R. D., Zeni, L., Haniu, M., Talvenheimo, J., Radka, S. F., Bennett, L., et al. (1995). Purification and identification of brainderived neurotrophic factor from human serum. Protein Expr. Purif. 6, 465-471. doi: 10.1006/prep.1995.1062

Sartorius, A., Hellweg, R., Litzke, J., Vogt, M., Dormann, C., Vollmayr, B., et al. (2009). Correlations and discrepancies between serum and brain tissue levels of neurotrophins after electroconvulsive treatment in rats. Pharmacopsychiatry 42, 270-276. doi: $10.1055 / \mathrm{s}-0029-1224162$
Sen, S., Duman, R., and Sanacora, G. (2008). Serum brain-derived neurotrophic factor, depression, and antidepressant medications: meta-analyses and implications. Biol. Psychiatry 64, 527-532. doi: 10.1016/j.biopsych.2008.05.005

Sheehan, D. V., Lecrubier, Y., Sheehan, K. H., Amorim, P., Janavas, J., and Weiller, E. (1998). The MiniInternational Neuropsychiatric Interview (M.I.N.I.): the development and validation of a structured diagnostic psychiatric interview for DSM-IV and ICD-10. J. Clin. Psychiatry 59, 22-33.

Smith, M. A., Makino, S., Kvetnansky, R., and Post, R. M. (1995). Stress and glucocorticoids affect the expression of brainderived neurotrophic factor and neurotrophin-3 mRNAs in the hippocampus. J. Neurosci. 15, 1768-1777.

Strohle, A., Stoy, M., Graetz, B., Scheel, M., Wittmann, A., Gallinat, J., et al. (2010). Acute exercise ameliorates reduced brain-derived neurotrophic factor in patients with panic disorder Psychoneuroendocrinology 35, 364-368.

Tadić, A., Müller-Engling, L., Schlicht, K. F., Kotsiari, A., Dreimüller, N., Kleimann, A., et al. (2013). Methylation of the promoter of brain-derived neurotrophic factor exon IV and antidepressant response in major depression. Mol. Psychiatry doi: 10.1038/mp.2013.58. [Epub ahead of print].

Tadić, A., Wagner, S., Schlicht, K. F., Peetz, D., Borysenko, L., Dreimüller, N., et al. (2011). The early non-increase of serum BDNF predicts failure of antidepressant treatment in patients with major depression: a pilot study. Prog. Neuropsychopharmacol. Biol. Psychiatry 35, 415-420. doi: 10.1016/j.pnpbp.2010.08.011

Trajkovska, V., Marcussen, A. B., Vinberg, M., Hartvig, P., Aznar, S., and Knudsen, G. M. (2007). Measurements of brain-derived neurotrophic factor: Methodological aspects and demographical data. Brain Res. Bull. 73, 143-149. doi: 10.1016/j.brainresbull.2007.03.009

Wang, Y., Mathews, C. A., Li, Y., Lin, Z., and Xiao, Z. (2011). Brain-derived neurotrophic factor (BDNF) plasma levels in drug-naïve OCD patients are lower than those in healthy people, but are not lower than those in drug-treated OCD patients. J. Affect. Disord.
133, 305-310. doi: 10.1016/j.jad. 2011.04.002

Wendland, J. R., Kruse, M. R., and Cromer, K. R. (2008). A large casecontrol study of common functional SLC6A4 and BDNF variants in obsessive-compulsive disorder Neuropsychopharmacology 33, 1476.

Wittchen, H. U., Robins, L. N., Cottler, L. B., Sartorius, N., Burke, J. D., and Regier, D. (1991). Cross-cultural feasibility, reliability and sources of variance of the Composite International Diagnostic Interview (CIDI). The multicentre WHO/ADAMHA field trials. Br. $J$. Psychiatry 159, 645-653.

Yamamoto, H., and Gurney, M. E. (1990). Human platelets contain brain-derived neurotrophic factor. J. Neurosci. 10, 3469-3478.

Yoshimura, R., Kaneko, S., Shinkai, K., and Nakamura, J. (2006). Successful treatment for obsessive-compulsive disorder with addition of lowdose risperidone to fluvoxamine: implications for plasma levels of catecholamine metabolites and serum brain-derived neurotrophic factor levels. Psychiatry Clin. Neurosci. 60, 389-393. doi: 10.1111/j.14401819.2006.01519.x

Ziegenhorn, A. A., SchulteHerbrüggen, O., Danker-Hopfe, H., Malbranc, M., Hartung, H. D., Anders, D., et al. (2007). Serum neurotrophins- A study on the time course and influencing factors in a large old age sample. Neurobiol. Aging 28, 1436-1445. doi: 10.1016/ j.neurobiolaging.2006.06.011

Conflict of Interest Statement: The authors declare that the research was conducted in the absence of any commercial or financial relationships that could be construed as a potential conflict of interest.

Received: 09 April 2013; paper pending published: 15 April 2013; accepted: 08 July 2013; published online: 29 July 2013. Citation: Suliman S, Hemmings SMJ and Seedat S (2013) Brain-Derived Neurotrophic Factor (BDNF) protein levels in anxiety disorders: systematic review and meta-regression analysis. Front. Integr. Neurosci. 7:55. doi: 10.3389/fnint.2013.00055

Copyright (๑) 2013 Suliman, Hemmings and Seedat. This is an open-access article distributed under the terms of the Creative Commons Attribution License, which permits use, distribution and reproduction in other forums, provided the original authors and source are credited and subject to any copyright notices concerning any third-party graphics etc. 